\title{
CORONAVIRUS AND THE NEED FOR STRONG GOVERNMENT INSTITUTIONS: DEFEATING THE PANDEMIC AND REVIVING ECONOMIES ${ }^{\circ}$
}

\author{
CORONAVIRUS Y LA NECESIDAD DE INSTITUCIONES \\ GUBERNAMENTALES FUERTES: DERROTANDO LA PANDEMIA Y \\ REACTIVANDO LAS ECONOMÍAS
}

Alexis S. Esposto*

enviado: 13 abril 2020 - aceptado: 17 abril 2020

\begin{abstract}
This paper discusses the importance of government and economic institutions in dealing with economic shocks such as the COVID-19. In attempting to deal with this massive health, social and economic upheaval, governments around the world have been using a variety of social and economic policies. These policies have two aims. First, to reduce the spread of the virus and second to mitigate the economy wide damage that the spread of the virus is causing. The paper describes the initial economic impact of the virus worldwide and on the Australian economy. It also argues that unless a rapid response is made, the likelihood of a world depression is high. The analysis focuses on the importance of government institutions in responding to major economic shocks. It showcases the work of the Treasury of Australia as a model of best practice for the development of economic policies designed to respond to extreme events. The paper concludes by providing a set of economy wide policy responses to tackle the current economic shocks.
\end{abstract}

JEL Code: H12, E02, I18.

Keywords: COVID-19, coronavirus, institutions, shocks, crisis, Australia.

Esposto, A. S. (2020). Coronavirus and the need for strong government institutions: defeating the pandemic and reviving economies. Estudios económicos, 37 (74), 205-217.

* Swinburne University of Technology (Australia). E-mail: aesposto@swin.edu.au 


\section{Resumen}

Este artículo discute la importancia de las instituciones gubernamentales y económicas para hacer frente a los shocks económicos como el COVID-19. En respuesta a este desafío, los gobiernos de muchas partes del mundo han estado utilizando una variedad de políticas, enfocadas en reducir la propagación del virus y tratar de mitigar el daño a la economía que el virus está ocasionando. Este documento describe el impacto económico inicial del virus en todo el mundo y en la economía australiana, apuntando una recesión o depresión mundial. El artículo proporciona una discusión sobre el papel del gobierno en la lucha contra las crisis económicas y ofrece un ejemplo de las mejores prácticas institucionales, en este caso el Ministerio de Hacienda australiano. Aquí se destaca la importancia de las instituciones gubernamentales para responder a los principales shocks económicos. El documento concluye brindando un conjunto de respuestas de política económica a los shocks económicos como el que estamos experimentando.

Código JEL: H12, E02, I18.

Palabras clave: COVID-19, coronavirus, instituciones, shocks, crisis, Australia. 


\section{INTRODUCTION}

'May you live in interesting times' is commonly known as the Chinese curse $^{1}$. Although this proverb is wrongly attributed as being of Chinese origin, its ironic nature states that life is better in uninteresting and boring times. It also suggests that a good life is characterised by peacefulness and an unexciting existence. Simply put, a good life is one that is devoid of pandemics, wars, climate change, famines, and other terrible calamities. Yet, to say that we are currently living in interesting times is probably an understatement. What we are experiencing in the world today and as a globalised community is unparalleled and extraordinary in history, to say the least. Since the spread of the COVID-19 virus, starting at a wet market in the city of Wuhan, China, the virus has been spreading at exponential rates around the world. To date ${ }^{2}$, the number of confirmed cases is nearing 1.9 million, having more doubled worldwide over the past 12 days. Meanwhile the number of reported deaths stands at nearly 115000 and climbing (Our World Data, 2020).

In attempting to deal with this massive health and social disaster and economic upheaval, governments around the world have been using a variety of policies, centred at reducing the spread of the virus and trying to mitigate the massive economy wide damage that the virus is wreaking in nations around the world. Central to the management of such social disruption and massive economic shocks, the role of institutions, both national and international has been crucial in responding to the onset of COVID-19.

Thus, the discussion that follows centres on the importance of economic and government institutions in dealing with economic shocks such as the one we are currently experiencing. The paper is organised as follows: Section I is the introduction. This is followed by an explanation of the impact of COVID-19 and the current economic shock being experienced both internationally and in Australia. Section III discusses why solid institutions are important in dealing with economic shocks and provides and example of how the Treasury of Australia's economic research was crucial in assisting in the design of current government policy. The final section provides a conclusion and offers a set of economy wide policy responses.

1 According to Van Norden (2011) there appears to be no equivalent Chinese expression.

2 I completed writing this article on 12 April, 2020. 


\section{THE CURRENT ECONOMIC SHOCK: THE WORLD ECONOMY}

We live in unprecedented economic times characterised by a massive economic shock that has rocked economic activity around the world. Governments all over the world have adopted a set of fiscal, and monetary and macro-financial policies designed to cushion the impact on local and international economies (e.g. IMF, 2020). According to Roubini (2020), the primary economic impact of the spread of COVID-19 has been to generate a major economic supply shock followed by a sharp decline in demand. A 'Supply shock' generates sharp reductions in the supply of goods and services. This is often accompanied by an almost instantaneous and rapid fall in demand for goods and services. In fact, if the supply shock is big enough (as it is now) and demand falls sharply, then every component in aggregate demand such as consumption, capital investment and exports fall sharply.

The current supply shock began with a rapid and unexpected full lockdown in most of the Chinese economy as news of COVID-19 emerged. It began in the Hubei Province and spread quickly throughout much of the country. This then spilled over to the majority of international markets. The most affected sectors at first were air travel, tourism, transport, entertainment, retail services and hotels, all of which amount to a substantial share of GDP in most economies around the world. This has now moved to other industrial sectors, including construction, car manufacturing and other related and non-related manufacturing, as well as other economy wide sectors (Nuno, 2020: 6). The health sector has not been exempt from this in developed economies. Large numbers of health workers have been infected by the virus, especially in the US, Italy and Spain, putting heavy strains on national health systems. Furthermore, the shutdown in international trade has collapsed supply chains that provide important medical equipment such as medical masks and ventilators. An example is the United States, where the availability of N95 medical masks are scarce in New York hospitals and in hospitals in other major US cities.

A casualty of these events have been small to medium sized enterprises (SMEs). When SMEs are forced to shut down, in order to protect the health of the wider population ${ }^{3}$, the first impact is that vast numbers of workers are stood down, or their working hours are severely reduced. This causes a negative cascading effect

3 For example, the Government of the State of Victoria Australia, is telling its citizens that there are four reasons to be outside: (i) shopping for what you need - food and essential supplies; (ii) medical, care or compassionate needs; (iii) exercise in compliance with the public gathering requirements; and (iv) work and study if you can’t work or learn remotely (Government of Victoria, 2020, Stage 3). 
whose economic impact is difficult to measure in the short term. Large businesses are also affected, especially those in the economic sectors mentioned earlier.

The economic impact on businesses is diverse. Forecasts conducted by Gormsen and Koijen (2020) show that annual dividends will likely decrease by $28 \%$ in the US and 22\% in the European Union. Meanwhile, GDP projections are likely to decline by $2.2 \%$ and $2.8 \%$ respectively, in both parts of the world within the next two quarters. In spite of these negative findings, the expectations appear to be much worse than what Gormsen and Koijen predict. According to Roubini, the real impact of the COVID-19 pandemic has already been harsher than the Global Financial Crisis of 2008 in almost every nation in the world. In early March,

... it took just 15 days for the US stock market to plummet into bear territory (a 20\% decline from its peak) - the fastest such decline ever. Now, markets are down $35 \%$, credit markets have seized up, and credit spreads (like those for junk bonds) have spiked to 2008 levels. Even mainstream financial firms such as Goldman Sachs, JP Morgan and Morgan Stanley expect US GDP to fall by an annualized rate of $6 \%$ in the first quarter, and by $24 \%$ to $30 \%$ in the second. US Treasury Secretary Steve Mnuchin has warned that the unemployment rate could skyrocket to above 20\% (twice the peak level during the GFC) (Roubini, 2020, para 2).

Gurría (2020a) reports that the initial impact of the containment measures were severely felt worldwide, with GDP declines of between 15 and 30\% for most OECD countries, including China (OECD, 2020). Gurría (2020b) suggests that the initial impact of lockdowns and shutdowns could be a fall in output levels of between 20 to $25 \%$ in most economies, followed by a decline in consumer spending of around 30\% (Gurría, 2020b: 2).

Taken together, the affected sectors account for between 30-40 per cent of total output in most economies. Allowing for only partial shutdowns in some sectors, and assuming a similar extent of shutdowns in all countries, the overall direct initial hit to the level of GDP is typically between 20-25\% in many major advanced economies (Gurría, 2020b: 2).

The actual effect on annual GDP growth around the world will actually depend on how long the crisis continues. Various commentators suggest a period of 6 to 18 months. Predicting how far GDP will fall is difficult to predict. 


\section{I.1. COVID-19: Impact on the Australian Economy}

The Australian economic situation is shaky to say the least. By the third quarter of 2019, it was already clear that the economy required some form of government economic stimulus by early 2020. A major reason was years of draught in key agricultural regions of the states of New South Wales and Queensland. These draughts were severely impacting on the agricultural sector. Yet worse was to come. At the start of 2020, Australia experienced bushfires that have been described as Australia's worst in its recorded history. Thirty-three people lost their lives (The Guardian, 2020). It also devastated highly productive lands, destroyed forests, homes, and millions of native animals. Described as "megafires" and producing destruction estimated at $\$ 100$ billion, the bushfires of November 2019 and January 2020, were described as ' ... 25 times the size of Australia's deadliest bushfires, the 2009 Black Saturday fires in Victoria that directly killed 173 people...” (Read and Dennis, 2020). The economic impact of bushfires in Australian regions is still evolving.

The onset of COVID-19 made matters worse. Recent research conducted by Westpac Bank's economics unit shows a bleak short-term outlook. The unit expects that the industries to suffer the most will include accommodation, recreation, retail, restaurants, construction, real estate and transport (p. 4). Furthermore, forecasts suggest a peak in the national unemployment rate of '.. $.11 .1 \%$ and a GDP contraction of $8.5 \%$ in the June quarter, as well as the likely issuance of an additional \$250bn in Australian government bonds over 2019/20 and 2020/21' (Westpac, p. 4). Other forecasts are more pessimistic, with the Commonwealth Bank predicting a contraction to GDP by $10 \%$.

For its part, the Australian Bureau of Statistics (ABS) recently conducted a survey that analysed the 'Incidence of Adverse Business Impacts'. Its survey found that half of Australian businesses (49\%) had experienced an adverse impact because of COVID-19 during the previous two weeks and $86 \%$ of businesses expected to be impacted in future months (ABS, 2020). Given this bleak situation, the Australian government has reacted swiftly in order to respond to the crisis.

\section{THE ROLE OF INSTITUTIONS: SOLID GOVERNMENT INSTITUTIONS REALLY MATTER}

The previous section has given a brief description of how COVID-19 is impacting on the world and Australian economies. Here I discuss the important 
role that institutions are playing in Australia in order to deal with the effects of the pandemic in an economic sense.

The interest and role in government institutions has arisen from the realization that they play an important role in times of crises such as the one we are currently living. Solid government institutions with a clear mandate have the ability to allocate resources quickly and efficiently, especially at times of social and economic emergency. A salient characteristic of institutions is that they influence the incentives that give rise to efficient economic performance (Acemoglu et al., 2004). Douglas North defines institutions as:

the humanly devised constraints that structure political, economic and social interaction. They consist of both formal and informal constraints (sanctions, taboos, customs, traditions, and codes of conduct), and formal rules (constitutions, laws, property rights) (1991: 97).

Institutions play a significant role in determining whether transaction costs are low or high and potentially generate a structure of incentives that foster economic growth and generate stability over the longer term (North, 1990). An important function of institutions is that they help allocate resources in the most efficient way by determining who gets profits, revenues and residual rights of control (Acemoglu et al., 2004: 2). Ali argues that institutions that operate successfully will provide a setting that will have a substantial impact on economic growth, while poorly functioning ones will hinder it by inducing economic agents to engage in redistributive behaviours that hinder growth (2003: 350). Other economists and social scientists have put forward the notion that good economic institutions, particularly in the public sector, are crucial and instrumental in generating both economic growth and development (eg. Gagliardi, 2008 \& La Porta et al., 1999: 222). Nelson (1994) defines institutions as the players participating in the game. This definition considers the role of those who have to apply the rules and ensure that those participating abide by them. Examples include government ministries, bodies and agencies, universities, industry groups, and hospitals.

Institutions matter because they help solve a key economic problem of agents coordinating their economic plans and activities, particularly as it relates to the functioning and role of government. Institutions that function well '... support the formation of social capital and of a historical experience of collective action which, in turn, positively affect the likelihood to credibility commitment in cooperative strategies (Gagliardi, 2008: 419). 
Banks $^{4}$ (2015) clearly explains why government institutions matter and what makes them work well.

A key lesson has been the critical importance of statutory backing for a body with an ongoing role in this area, given the need for independent assessments and preparedness to give advice to government that may not always be wanted or welcome. There have been multiple occasions in the Commission's long history when it was so unpopular with certain interest groups that the government of the day could well have found it politically expedient to abolish it. Having its own legislation need not have precluded this, but it necessitated making a case that would gain wider support (2122).

Banks (2015) also argues that there is a powerful case for the creation and improvement of government institutions that not just help government identify the right policies, but also informs the government of the day, on how best to apply such policies. One such example of a successful government institution is the Treasury of Australia ${ }^{5}$, which in $2006^{6}$ already had a strategy to assist the Australian Federal Government on how to tackle a possible pandemic. It is important to note, here, that thanks to the Westminster system of government, Australia has a public service that overall functions independently from the Parliamentary political government. In terms of government policy, its role and purpose is to provide objective advice at arms length, without fear or favour to the government of the day.

\section{II.1. The Treasury’s Plan of 2006 and the Government Response in 2020}

Planning is essential to deal with severe economic shocks such as the one we are experiencing in Australia and the world at large. To understand the current government's economic strategy, we need to go back to an obscure yet, powerful and anticipating Working Paper written by Kennedy et al. in 20067. Titled 'A primer

4 Gary Banks was Chair of the Productivity Commission from 17 April 1998 to 31 December 2012.

5 In 2005, the Australian Department of Health and Ageing had already developed a Draft Australian Management Plan for Pandemic Influenza. The Department of the Treasury (or The Treasury) is the Australian Government department responsible for economic policy, fiscal policy, market regulation, and the Australian federal budget. It has been operational since Federation in 1901.

6 The Department of the Treasury (or The Treasury) is the Australian Government department responsible for economic policy, fiscal policy, market regulation, and the Australian federal budget. It has been operational since Federation in 1901.

7 It is interesting to note that the mainstream media has placed enormous focus on the contribution of 
on the macroeconomic effects of an influenza pandemic', the paper details an economic strategy to deal with an influenza pandemic in Australia. The primary author is Steven Kennedy who is currently the Treasury's secretary and his co-authors (Thomson \& Vujanovic) detail a strategy that has given the current government a set of policies and strategies that it is implementing almost in full.

The paper discussed different economic scenarios and pathways through which a pandemic was likely to impact on Australia's population. Three pathways were simulated using the Treasury Macro-econometric model (TRYM). The results produced by TRYM's scenarios warned of the scale of the major shocks that Australia would face. Based on their simulations, the authors warned:

\begin{abstract}
A pandemic will have short-run demand effects and both short-run and long-run supply effects. In the short-run, the supply-side effects are largely negative and affect both aggregate and per capita output. The biggest shortrun supply effects relate to labour supply and temporary business closures due both to people getting sick and to people staying home to avoid infection or to care for friends or relatives who have become sick (Kennedy et al. 2006: 7).
\end{abstract}

By analysing the impact of viral outbreaks Kennedy's team identified and quantified six economic shocks. These were: (i) world demand shocks; (ii) deaths; (iii) labour force; (iv) confidence effects in consumption; (v) business and dwelling investment; and (vi) medium term dynamic effects, in other words, an economic simulation beyond the short term.

Armed with this information at the start of 2020, the Federal government arranged consultative meetings with its State government counterparts and other relevant government agencies and departments. Its policy response was to ensure the maintenance of economic confidence in Australia. This is currently being done by injecting spending on COVID-19 related measures via the implementation of aggressive fiscal and monetary policies. One such target is to stimulate Australia's consumer spending which stands at around $60 \%$ of GDP. Another is to ensure that people remain active in the workforce, or at least are able to survive the coming difficult months. A key government measure is the introduction of a wage subsidy program to support employees and businesses. The idea is to assist mainly small

celebrities and billionaires such as Bill Gates in warning us of the consequences of pandemics. Yet the amazing work of quite achievers such as Kennedy et al. and thousands of hardworking scientists, whom celebrities and billionaires rely on for their own publicity, are largely ignored. 
and medium sized enterprises to pay their employees' wages while the crisis continues. The scheme allows employers who stood down their employees before the commencement of this scheme are also able to access this government plan.

Other stimulus packages include the following initiatives: (i) delivering support for business investment; (ii) cash flow assistance for businesses; (iii) stimulus payments to households to support growth, including a $\$ 750$ payment to social security recipients; and (iv) assistance for severely affected regions (Treasury, 2020). In total, the whole of the measures implemented are estimated to cost at least $\$ 190$ billion.

\section{CONCLUSION AND POLICY IMPLICATIONS}

The previous section illustrated the important role that solid institutions play in assisting nations dealing with pandemics and massive economic shocks. It also provided an example of institutional best practice.

The COVID-19 pandemic will eventually disappear as others have done in the past. The challenge for governments then and now will be to generate confidence in the economy and the population at large as it recovers from the loss of life and economic activity caused by the pandemic. Therefore, to ensure that the economy recovers quickly, the task of government institutions is to develop evidenced based policies that are not tarnished by ideology. The aims of such policies is to generate confidence in the economy thus promoting growth in aggregate demand.

To do this, policy makers will need to use the best of what is available in the arsenal of economic policies. Such policies should, given the dire circumstances that Roubini and others assert, include the use of Modern Monetary Theory. This could be implemented by utilising Friedman's 'helicopter money' in the form of direct cash payment to households. The effect of this policy is a direct cash injection to households. Cash injections to SMEs will also be indispensable in order to stimulate labour demand. This will be needed because labour supply by households will recover almost instantaneously, whereas demand for labour by businesses will be slow to recover. A payroll tax break will also be beneficial for businesses. Furthermore, the promotion of policies to encourage innovation by firms should include government funding for research and development, direct and indirect subsidies and tax concessions, as well as the promotion of high value added manufacturing. 
Subsidising large businesses is an area where governments need to tread carefully. Handouts to large corporations which already face high levels of debt should not be encouraged. In these circumstances, the creative destruction process of capitalism should run its natural course. There is no need for governments to pour billions of dollars to save, for example an airline, when allowing it to fail may allow other more efficient carriers to take its place and create a more competitive national economic environment. This would greatly benefit consumers and create more jobs.

In terms of international trade, the promotion of exports of primary products and commodities will be essential in kick starting key sectors such as agriculture. Finally, governments around the world will need more cooperation rather than less in responding to the health challenge. After all, we are all facing the same challenges.

\section{REFERENCES}

Acemoglu, D., Johnson, S. \& Robinson, J. (2004). Institutions as the Fundamental Cause of Long-Run Growth, Working Paper no. 10481, Cambridge, Massachusetts: National Bureau of Economic Research.

Ali, A. (2003). Institutional Differences as Sources of Growth Differences. Atlantic Economic Journal, 31 (4), 348-362.

Australian Bureau of Statistics (2020). 5676.0.55.003, Business Indicators, Business Impacts of COVID-19'. ABS, viewed 12 April 2020. Recovered from https://www.abs.gov.au/AUSSTATS/abs@.nsf/Lookup/5676.0.55.003Mai n+Features1March\%202020

Australian Department of Health and Ageing (2005). Draft Australian Management Plan for Pandemic Influenza. Department of Health.

Australian Government (2020). JobKeeper Payment: Supporting businesses to retain jobs, Fact sheet: Economic Response to the Coronavirus, viewed 12 April 2020. Recovered from https://treasury.gov.au/sites/default/files/202004/Fact_sheet_supporting_businesses_0.pdf

Banks, G. (2015). Institutions to Promote Pro-Productivity Policies Logic and Lessons, OECD Productivity, Working Paper no. 1. Paris: OECD Publishing. Recovered from https://doi.org/10.1787/5jrql2tsvh41-en

Esposto, A. \& Tohmé, F. (2009). Drifting Apart: The Divergent Development Paths of Argentina and Australia. Saarbrücken, Germany: VDM Verlag Dr Müller. 
Fernandes, N. (2020). Economic effects of coronavirus outbreak (COVID-19) on the world economy, viewed 12 April 2020. Recovered from https://papers. ssrn.com/sol3/papers.cfm?abstract_id=3557504

Financial Standard (2020). GDP to contract 10\%: CBA, 2 April 2020, viewed 12 April 2020. Recovered from https://www.financialstandard.com.au/news/ gdp-to-contract-10-cba-157300816

Gagliardi, F. (2008). Institutions and Economic Change: A Critical Survey of the New Institutional Approaches and Empirical Evidence. Journal of SocioEconomics, 37(1), 416-443.

Gormsen, N. J. \& Koijen, R. S. (2020). Coronavirus: Impact on stock prices and growth expectations, University of Chicago, Becker Friedman Institute for Economics, Working Paper no. 2020-22.

Gurría, A. (2020a). Tackling coronavirus (COVID-19) Contributing to a global effort. Organisation for Economic Co-operation and Development (OECD), viewed 12 April 2020. Recovered from https://www.oecd.org/coronavirus/ en/

Gurría, A. (2020b). Evaluating the initial impact of COVID-19 containment measures on economic activity. Organisation for Economic Co-operation and Development (OECD), viewed 12 April 2020. Recovered from https://www. oecd.org/coronavirus/en/

Government of Victoria (2020). Coronavirus (COVID-19) restrictions Victoria, 10am, 31 March 2020, viewed 12 April 2020. Recovered from https://www. vic.gov.au/coronavirus-covid-19-restrictions-victoria

International Monetary Fund (IMF). (2020). Policy Responses to COVID-19, viewed 12 April 2020. Recovered from https://www.imf.org/en/Topics/ imf-and-covid19/Policy-Responses-to-COVID-19

Kennedy, S., Thomson, J. \& Vujanovic, P. (2006). A primer on the macroeconomic effects of an influenza pandemic. Working Paper no. 2006-01. The Treasury, Australian Government.

Nelson, R. R. (1994). The Co-evolution of Technology, Industrial Structure, and Supporting Institutions. Industrial and Corporate Change, 3 (1), 47-63.

North, D. (1990). Institutions, Institutional Change and Economic Performance. Cambridge: University Press.

North, D. (1991), Institutions. Journal of Economic Perspectives, 5 (1), 97-112.

Our World Data (2020). Growth in COVID-19 cases, by country, viewed 13 April 2020. Recovered from https://ourworldindata.org/coronavirus\#cases-ofcovid-19 
Perényi, Á., Esposto, A. \& Bamforth, J. (2020). Institutional transformation and development from an economic transition perspective: the case of Argentina. Journal of Institutional Economics, 16 (1), 83-104.

Read, P. \& Dennis, R. (2020). With costs approaching $\$ 100$ billion, the fires are Australia's costliest natural disaster, The Conversation, January 17, 2020, viewed 121 April 2020, Recovered from https://theconversation.com/withcosts-approaching-100-billion-the-fires-are-australias-costliest-naturaldisaster-129433

PricewaterhouseCoopers (PwC) (2020). The possible economic consequences of a novel coronavirus (COVID-19) pandemic, viewed 12 April 2020. Recovered from https://www.pwc.com.au/publications/australia-matters/economicconsequences-coronavirus-COVID-19-pandemic.pdf

Roubini, N. (2020). A Greater Depression? Project Syndicate, 24 March, viewed 12 April 2020. Recovered from https://www.project-syndicate.org/commentary/coronavirus-greater-great-depression-by-nouriel-roubini-2020-03

The Guardian (2020). Mothers, daughters, fathers, sons: the victims of the Australian bushfires, 24 January 2020, viewed 12 April 2020. Recovered from https://www.theguardian.com/australia-news/2020/jan/02/mothers-daughters-fathers-sons-the-victims-of-the-australian-bushfires

The Treasury, Australian Government (2020). Economic Response to the Coronavirus. AG, viewed 12 April, 2020, Recovered from https://treasury.gov.au/ sites/default/files/2020-03/Overview-Economic_Response_to_the_Coronavirus.pdf

Van Norden, B.W. (2011). Introduction to classical Chinese philosophy. Indianapolis: Hackett Publishing.

Westpac Economics (2020). Westpac Coast-to-Coast April 2020: An update on Australia's State Economies. WIB, viewed 12 April 2020. Recovered from https://westpaciq.westpac.com.au/wibiqauthoring/_uploads/file/Australia/2020/April/WestpacCoasttoCoastApril2020.pdf

(C) 2020 por los autores; licencia no exclusiva otorgada a la revista Estudios económicos. Este artículo es de acceso abierto y distribuido bajo los términos y condiciones de una licencia Atribución-No Comercial 4.0 Internacional (CC BY-NC 4.0) de Creative Commons. Para ver una copia de esta licencia, visite http:// creativecommons.org/licenses/by-nc/4.0 
